\title{
Newly isolated Bacillus sp. G51 from Patagonian wool produces an enzyme combination suitable for felt-resist treatments of organic wool
}

\author{
Martín S. Iglesias $^{1} \cdot$ Cynthia Sequeiros $^{2} \cdot$ Sebastián García $^{3} \cdot$ Nelda L. Olivera $^{1}$
}

Received: 6 December 2016 / Accepted: 30 January 2017

(C) Springer-Verlag Berlin Heidelberg 2017

\begin{abstract}
Bacteria from Patagonian Merino wool were isolated to assess their wool-keratinolytic activity and potential for felt-resist treatments. Strains from Bacillus, Exiguobacterium, Deinococcus, and Micrococcus produced wool-degrading enzymes. Bacillus sp. G51 showed the highest wool-keratinolytic activity. LC-MS/ MS analysis revealed that G51 secreted two serine proteases belonging to the peptidase family S8 (MEROPS) and a metalloprotease associated with Bacillolysin, along with other enzymes ( $\gamma$-glutamyltranspeptidase and dihydrolipoyl dehydrogenases) that could be involved in reduction of keratin disulfide bonds. Optimum $\mathrm{pH}$ and temperature of G51 proteolytic activity were 9 and $60^{\circ} \mathrm{C}$, respectively. More than $80 \%$ of activity was retained in $\mathrm{H}_{2} \mathrm{O}_{2}$, Triton X-100, Tween 20, Lipocol OXO650, Teridol $\mathrm{B}$, and $\beta$-mercaptoethanol. Treatment of wool top with G51 enzyme extract caused a decrease in wool felting tendency without significant weight loss $(<1.5 \%)$. Sparse work has so far been performed to investigate suitable keratinases for the organic wool sector. This eco-friendly treatment based
\end{abstract}

Electronic supplementary material The online version of this article (doi:10.1007/s00449-017-1748-4) contains supplementary material, which is available to authorized users.

Nelda L. Olivera

olivera@cenpat-conicet.gob.ar

1 Instituto Patagónico para el Estudio de los Ecosistemas Continentales (IPEEC-CCT CENPAT-CONICET), Blvd. Brown 2915, Puerto Madryn, Chubut, Argentina

2 Centro para el Estudio de Sistemas Marinos (CESIMARCCT CENPAT- CONICET), Blvd. Brown 2915, Puerto Madryn, Chubut, Argentina

3 Centro INTI-CHUBUT, Calle G. Lobato 3531, Parque Industrial, Trelew, Chubut, Argentina on a new enzyme combination produced by a wild bacterium has potential for meeting the demands of organic wool processing which bans the use of hazardous chemicals and genetic engineering.

Keywords Organic wool $\cdot$ Felting $\cdot$ Keratinases · Bacillus · Patagonia

\section{Introduction}

Wool is an animal hair fiber that consists mainly on proteins (up to 90-95\% of the fiber) of two major types, the intermediate filament forming keratin proteins and the keratin associated proteins [1]. The wool surface is formed by overlapping hydrophobic cuticle scales that cover the cortex cells in the interior of the fiber [2]. During aqueous washing, the scale structure of the cuticle and the associated differential friction effect lead to a progressive entanglement of the wool fiber, resulting in felting shrinkage [3]. The commercial most common process for imparting shrink resistance to wool is the chlorine-Hercosett method which combines acid chlorination followed by a cationic polyamide epichlorhydrin polymer application [4]. Drawbacks of this process may include yellowing of wool, fiber strength loss, poor handling quality, and harmful effluents containing absorbable organic halogens (AOX) [5]. Thus, one of the main need is the development of environmentally friendly felt-resist treatments which permit wool washing in domestic machines. This is even more important for the organic wool sector which requires processes with low environmental impacts. Ladwig et al. [6] reported that, globally, approximately $1 \%$ of the sheep are organically managed with a total flock in 2013 of almost 12 million, which could achieve a $10-15 \%$ premium over non-organic prices. 
The improvement of wool fiber attributes could contribute to the valorization of organic wool, expanding their opportunities for growth in the global wool market. The Global Organic Textile Standard (GOTS) defines the world processing standard for textiles made from organic fibers, including wool. Chlorination of wool is prohibited by GOTS [7] due to the individual health and environmental risks. Enzymatic shrink-resist treatments arose among chlorine-free processes because proteases with keratinolytic activity can be used for wool descaling to improve shrink resistance [8]. Cegarra et al. [9] modeled the action of the enzyme Novolan T (Novo Nordisk), produced by a genetically modified Bacillus strain, on the physical characteristics of a wool fabric and determined the optimal treatment conditions. Other biocatalysts, Bactosol WO (Sandoz Chemikalien AG) and Savinase/Novozym (Novo Nordisk), had a positive influence on wool fiber properties inducing a decrease in shrinkage [10]. Lenting et al. [11] showed that a pre-treatment with hydrogen peroxide and high salt concentration modify specifically the outer surface protein layer of wool making this fiber susceptible for proteolytic hydrolysis, which resulted in shrink resistance with a limited impact on tensile strength loss. To restrict protease activity to the wool cuticle and avoid an excessive damage of the fiber, different approaches such as chemical and genetical modification of proteases have proved to be useful [12-14]. For example, wool anti-felting effect and improved control on enzyme activity were reached using Esperase covalently linked onto Eudragit S100 [13]. A recombinant high molecular weight protease, subtilisinE-VPAVG ${ }_{220}$, produced a significant reduction of pilling, weight loss, and tensile strength loss of wool fibers in comparison with Esperase (Sigma-Aldrich) [12]. Another recombinant protease proposed to prevent wool shrinkage was an extreme alkaline, oxidation-resistant keratinase from Bacillus licheniformis BBE11-1 expressed in Bacillus subtilis WB600 [15].

Despite the number of studies about application of keratinases to reduce wool-shrink tendency, sparse work has so far been performed to investigate suitable keratinases for organic wool processing. Besides rejecting wool chlorination, GOTS prohibits the use of enzymes derived from genetically modified organisms in textile processing [7]. Nowadays, genetically modified (engineered) microorganisms (GMM) are generally used to produce commercial Subtilisins, to enhance productivity or to introduce desired traits such as stability enhancement [16]. Most of the proteases investigated to date for improving wool shrinkresistance are commercial Subtilisins or enzymes derived from GMM. The isolation and screening of wild keratinolytic strains from natural environments or wool sheep could, therefore, open new opportunities for the development of felt-resist treatments of organic wool based on novel keratinases. Accordingly, the aim of this study was to isolate native bacteria from Patagonian Merino wool to characterize their keratinolytic enzymes and to assess their potential for felt-resist treatments suitable for organic wool processing.

\section{Materials and methods}

\section{Isolation of protease-producing bacteria}

Samples of raw Merino wool were collected from 5 sheep shearing zones in Patagonia (Argentina): Río Negro Province (Norquinco), Tierra del Fuego Province, and Chubut Province (Meseta Central and two sheep breeding ranches near to Puerto Madryn city). To enhance the possibilities of isolating protease-producing microorganisms, the samples were processed by two methods: direct platting on Skim milk (SM) and Humic acid-vitamin (HAV) agar, and protease-producing microorganism enrichment and platting on SM agar. Thus, each wool sample was divided in two subsamples, one of them suspended in sterile saline solution was used to spread SM and HAV agar plates. SM agar contained $(\mathrm{g} / \mathrm{L}$ in distilled water) skim milk 12.5 , yeast extract $3, \mathrm{NaCl} 5$, agar-agar 16 (pH 7.8). HAV agar was prepared according to Hayakawa et al. [17]. The second wool subsample was incubated in a mineral salt medium MSM ( $\mathrm{g} / \mathrm{L}$ in distilled water $\mathrm{K}_{2} \mathrm{HPO}_{4} \cdot 3 \mathrm{H}_{2} \mathrm{O} 1.5 ; \mathrm{MgSO}_{4} \cdot 7 \mathrm{H}_{2} \mathrm{O} 0.1$; $\left.\mathrm{CaCl}_{2} 0.1 ; \mathrm{FeSO}_{4} \cdot 7 \mathrm{H}_{2} \mathrm{O} 0.03 ; \mathrm{ZnSO}_{4} \cdot 7 \mathrm{H}_{2} \mathrm{O} 0.005\right)$ at $30^{\circ} \mathrm{C}$ and $200 \mathrm{rpm}$ for 5 days. In this medium, wool was the only source of carbon and nitrogen which favors the development of microorganisms that release extracellular proteases to depolymerize keratin [18]. Microorganisms grown in both HAV agar and MSM were sub-cultured on SM agar to detect protease activity. The SM agar plates were incubated at $30^{\circ} \mathrm{C}$ and observed daily for signs of clearing of the agar around the colonies during 5 days. The proteolytic isolates were purified by repeated streaking in the same medium and stored at $-80^{\circ} \mathrm{C}$ using $20 \%(\mathrm{v} / \mathrm{v})$ glycerol as cryoprotectant.

\section{Screening of protease-producing bacteria}

To select the isolates with the higher protease activity, a spot technique on SM agar was used [19]. For each isolate, three $100 \mathrm{~mL}$ Erlenmeyer flasks containing $30 \mathrm{~mL}$ of SM liquid medium were inoculated with an overnight culture at $5 \%(\mathrm{v} / \mathrm{v})$ ratio and incubated at $30^{\circ} \mathrm{C}$ and $200 \mathrm{rpm}$ in an orbital shaker for $72 \mathrm{~h}$. The cultures were centrifuged $\left(4^{\circ} \mathrm{C}\right.$, $16,200 \mathrm{~g}, 10 \mathrm{~min})$ and the supernatants $(5 \mu \mathrm{L})$ were placed on SM agar plates. Halos generated by proteolytic activity were recorded every day for a 3 day-period at $30^{\circ} \mathrm{C}$. The 
strains showing a clearance diameter $>0.5 \mathrm{~cm}$ at day 1 and $>1 \mathrm{~cm}$ at day 3 were selected for further studies.

\section{S rDNA amplification and sequencing}

DNA from isolates was extracted using the Wizard Genomic DNA Purification kit (Promega Corporation, Madison, USA). In a first step, almost $500 \mathrm{bp}$ of the $16 \mathrm{~S}$ rRNA gene of the isolates was sequenced using the primers $27 \mathrm{f}$ and $518 \mathrm{r}$. For the selected isolate G51, the 16S rRNA gene sequence (corresponding to positions 27-1492 in the Escherichia coli gene) was PCR-amplified as described in Olivera et al. [20], using a Multigene Gradient thermal cycler (Labnet International Inc., Woodbridge, USA). Sequencing on both strands of PCR-amplified fragments was performed using the dideoxy chain termination method by the commercial services of IDEGEN (Argentina). The 16S rRNA gene sequences were compared to the GenBank nucleotide database with BLAST and identified using the EzTaxon-e program [21]. Sequences were deposited at the GenBank database under the accession numbers KX353764-KX353773.

\section{Keratinolytic activity}

Keratinolytic activity was examined using wool top as substrate. Wool fibers were cut into small fragments, ground well, and passed through a small-mesh grid to remove coarse particles [22]. One milliliter of culture supernatant (see "Screening of protease-producing bacteria") was incubated with $1 \%$ (w/v) milled wool $(1 \mathrm{~mL})$, in $50 \mathrm{mM}$ TRIS-HCl buffer (pH 8.0) at $45^{\circ} \mathrm{C}$ and $100 \mathrm{rpm}$ for $2 \mathrm{~h}$. The reaction was terminated with $2 \mathrm{~mL}$ of $10 \%$ (w/v) trichloroacetic acid (TCA) and then, the reactants were allowed to stand for $30 \mathrm{~min}$ at $4{ }^{\circ} \mathrm{C}$. Controls were treated the same way except that TCA was added before the incubation. After centrifugation $(10,000 \mathrm{~g}, 10 \mathrm{~min}), 1 \mathrm{~mL}$ of the supernatant was added with $5 \mathrm{~mL}$ of $0.5 \mathrm{M} \mathrm{Na}_{2} \mathrm{CO}_{3}$ and $1 \mathrm{~mL}$ of Folin-Ciocalteu reagent, and then the mixture was incubated at $37^{\circ} \mathrm{C}$ for $30 \mathrm{~min}$ [23]. The keratinolytic activity was measured at $660 \mathrm{~nm}$ with a JENWAY 6320D visible spectrophotometer (Dunmow, Essex, UK). The data presented are mean values of three independent determinations. One keratinolytic activity unit (KAU) was defined as the amount of enzyme which liberates $1 \mu \mathrm{mol}$ tyrosine/min under the assay conditions.

\section{Caseinolytic Activity}

The reaction mixture contained $1.1 \mathrm{~mL}$ of $1 \%(\mathrm{w} / \mathrm{v})$ casein (SIGMA) in 0.1 M TRIS-HCl buffer (pH 8.0) and $0.1 \mathrm{~mL}$ of enzyme extract. The reaction was carried out at $45^{\circ} \mathrm{C}$ and stopped by the addition of $5 \%(\mathrm{w} / \mathrm{v})$ TCA
$(1.8 \mathrm{~mL})$. The controls were treated the same way except that TCA was added before the incubation. The reactants were allowed to stand at $4{ }^{\circ} \mathrm{C}$ for $30 \mathrm{~min}$, and centrifuged $(10,000 \mathrm{~g}, 10 \mathrm{~min})$. Caseinolytic activity was then determined spectrophotometrically using the Folin-Ciocalteu method [23]. The results were calculated as mean values of three independent replicas. One caseinolytic activity unit (CAU) was defined as the amount of enzyme which liberates $1 \mu \mathrm{mol}$ tyrosine/min under the assay conditions.

\section{Characterization of the proteolytic activity of isolate G51}

Influence of temperature, $p H$, and chemical agents on proteolytic activity

The proteolytic activity of the cell-free supernatant of the selected isolate G51 was characterized. A range of temperatures between 30 and $70^{\circ} \mathrm{C}$ were used for determining the optimum temperature of caseinolytic activity. Similarity, optimum $\mathrm{pH}$ was determined by assaying different pH buffers $\left[0.067 \mathrm{M} \mathrm{KH}_{2} \mathrm{PO}_{4}-\mathrm{Na}_{2} \mathrm{HPO}_{4}\right.$ (pH 6-7), $0.2 \mathrm{M}$ TRIS-HCl (pH 8-9), $0.2 \mathrm{M} \mathrm{Na}_{2} \mathrm{CO}_{3}-\mathrm{NaHCO}_{3}$ (pH 10)]. Thermostability was investigated by pre-incubating G51 supernatant without substrate at $40,50,60$, and $70^{\circ} \mathrm{C}$ from 0 to $120 \mathrm{~min}$, before measuring the residual caseinolytic activity. To determine $\mathrm{pH}$ stability, the cell-free supernatant was precipitated with three volumes of cold acetone $\left(-20^{\circ} \mathrm{C}\right)$, centrifuged $\left(4^{\circ} \mathrm{C}, 16,200 \mathrm{~g}, 10 \mathrm{~min}\right)$, and re-dissolved in the same initial volume of Good's buffers ( $\mathrm{pH}$ 6-10) [24] and $50 \mathrm{mM} \mathrm{Na}{ }_{2} \mathrm{HPO}_{4}-\mathrm{NaOH}$ buffer (pH 11). The $\mathrm{pH}$ stability (residual caseinolytic activity) was determined after left the samples on ice for $120 \mathrm{~min}$. Caseinolytic activity at minute zero was considered as $100 \%$ residual activity. The effects of $\mathrm{Ca}^{2+}$ and $\mathrm{Zn}^{2+}\left(5 \mathrm{mM} \mathrm{CaCl}_{2}\right.$ and $5 \mathrm{mM} \mathrm{ZnSO}_{4}$ ), surfactants ( 1 and 5\% v/v Tween 20, 1 and $5 \% \mathrm{v} / \mathrm{v}$ Triton X-100, $1 \% \mathrm{w} / \mathrm{v}$ SDS), surfactants/emulsifiers used in the wool industry (1\% v/v Lipocol OXO 650 and Teridol B), protease inhibitors (10 mM 1,10-phenanthroline, 0.1 mM E64, 1-10 mM PMSF, $0.1 \mathrm{mM}$ iodoacetamide, $10 \mathrm{mM}$ EDTA), and reducing /oxidizing agents (5 mM $\beta$-mercaptoethanol, $5 \mathrm{mM}$ DTT, $1 \% \mathrm{H}_{2} \mathrm{O}_{2}$ ) on caseinolytic activity were investigated after pre-incubating the G51 cell-free supernatant with such chemicals at $30^{\circ} \mathrm{C}$ for $1 \mathrm{~h}$. Controls were prepared by pre-incubating the samples with the appropriate solvents used to dissolve the chemicals assayed. The results were calculated as mean values of three independent replicas.

\section{SDS-PAGE/zymographic assay}

G51 cell-free supernatant $(400 \mu \mathrm{L})$ was precipitated with three volumes of cold acetone $\left(-20^{\circ} \mathrm{C}\right)$ with gentle 
agitation. The suspension was settled at $-20^{\circ} \mathrm{C}$ for $1 \mathrm{~h}$, and then it was centrifuged $\left(4^{\circ} \mathrm{C}, 10,000 \mathrm{~g}, 10 \mathrm{~min}\right)$. The pellet was dried under vacuum and it was re-dissolved in $50 \mu \mathrm{L}$ of $65 \mathrm{mM}$ TRIS-HCl (pH 6.8) containing 2\% (w/v) SDS, $8 \%$ glycerol, and $0.002 \%$ (w/v) bromophenol blue (protein content: $1.25 \mathrm{mg} / \mathrm{mL})$. SDS-PAGE (10.0\%) was performed in a Mini-Protean II Dual Slab Cell (BioRad, Hercules, USA) at constant voltage (200 volts) for $60 \mathrm{~min}$. Resolution buffer contained $3 \mathrm{M}$ TRIS- $\mathrm{HCl}(\mathrm{pH} 8.8)$ with $1 \%$ (w/v) SDS, and reservoir buffer $25 \mathrm{mM}$ TRIS- $\mathrm{HCl}(\mathrm{pH} 8.3)$ with $0.192 \mathrm{M}$ glycine and $0.1 \%$ (w/v) SDS. Samples were loaded together with a molecular weight marker (Low Range, Bio$\mathrm{Rad})$. Proteins were detected by colloidal staining with Coomassie brilliant blue G-250 [25]. Zymographic analysis was performed according to Westergaard et al. [26].

\section{Analysis of proteins by LC-MS/MS}

Detectable SDS-PAGE protein bands which showed proteolytic activity in zymographic analysis were excised from the gel. Protein digestion and Mass Spectrometry analysis (LC-MS/MS) were performed at the Proteomics Core Facility CEQUIBIEM, at the University of Buenos Aires/CONICET as follows: excised protein bands were sequentially washed with $50 \mathrm{mM}$ ammonium bicarbonate, $25 \mathrm{mM}$ ammonium bicarbonate 50\% acetonitrile, and 100\% acetonitrile; reduced and alkylated with $10 \mathrm{mM}$ DTT and $20 \mathrm{mM}$ iodoacetamide and in-gel digested with $120 \mathrm{ng}$ of trypsin in $25 \mathrm{mM}$ ammonium bicarbonate at $37^{\circ} \mathrm{C}$ overnight. Peptides were recovered by elution with $50 \%$ acetonitrile- $0.5 \%$ trifluroacetic acid, including brief sonication, and further concentrated by speed-vacuum drying. Samples were resuspended in $15 \mu \mathrm{L}$ of water containing $0.1 \%$ formic acid and desalted using C18 zip tips (Merck Millipore) and eluted in $10 \mu \mathrm{L}$ of $\mathrm{H}_{2} \mathrm{O}$ :ACN:FA 40:60:0.1\%.

The digests were analyzed by nanoLC-MS/MS in a Thermo Scientific Q Exactive Mass Spectrometer (Thermo Scientific, Bremen, Germany). A 120 min gradient of $\mathrm{H}_{2} \mathrm{O}: \mathrm{ACN}$ at a flow of $300 \mathrm{~nL} / \mathrm{min}$ was used with a C18 $2 \mathrm{~mm}$ Easy Spray column $\times 150 \mathrm{~mm}$. Data Dependent MS2 method was used to fragment the top 12 peaks in each cycle. Mass spectrometry data were first analyzed by generating .msf files from raw MS and MS/MS spectra using the Proteome Discoverer 1.4 software (Thermo Fisher Scientific) and the database searches were then performed using the SEQUEST search engine, against the Bacillus subtilis Uniprot protein sequence database. The following search parameters were applied; enzyme: trypsin (full); missed cleavage sites, 2; precursor mass tolerance, $10 \mathrm{ppm}$; fragment mass tolerance: $0.05 \mathrm{Da}$; Dynamic modifications: oxidation (M); fixed modifications: carbamidomethyl (C). Proteins were considered as significant hits if the following conditions were met: false discovery rate (FDR) less than $1 \%$; identified by at least two different high confidence peptides.

\section{Treatment of wool fibers using proteases from isolate G51}

\section{Analysis of wool surface modification}

Merino wool tops used in these studies were kindly supplied by Fuhrmann S.A. (Trelew, Argentina). To evaluate whether isolate G51 proteases could be used to degrade wool cuticle, $200 \mathrm{mg}$ of wool top fibers $(19.4 \mu \mathrm{m})$ were soaked in a solution consisting on $10 \mathrm{~mL}$ of G51 free-cell supernatant and $10 \mathrm{~mL}$ of $50 \mathrm{mM}$ TRIS-HCl buffer $(\mathrm{pH}$ 8.0) with gentle shaking $(50 \mathrm{rpm})$ at $50^{\circ} \mathrm{C}$ for $2 \mathrm{~h}$. Then, wool fibers were washed extensively with distilled water and air dried. Controls using Esperase 8.0 L (SIGMA) and without enzymes (only with buffer) were performed. The final concentration of G51 proteases and Esperase was approximately $1.5 \mathrm{CAU} / \mathrm{mL}$ of the bath. Aliquots of the wool fibers were subjected to scanning electron microscopy (SEM) to identify any surface modifications using a JEOL JSM 6460LV scanning electron microscope (JEOL, Tokyo, Japan) with an accelerating voltage of $15 \mathrm{kV}$.

\section{Enzymatic felt-resist treatment}

G51 enzyme extract was prepared by precipitation of the cell-free supernatant with three volumes of cold acetone $\left(-20^{\circ} \mathrm{C}\right)$. After centrifugation $\left(4^{\circ} \mathrm{C}, 16,200 \mathrm{~g}, 10 \mathrm{~min}\right)$, the pellet was re-dissolved in $50 \mathrm{mM}$ TRIS-HCl buffer $(\mathrm{pH}$ 8.0). Approximately $1.1 \mathrm{~g}$ of wool top $(23.5 \mu \mathrm{m})$ was disposed in a bath (mass:liquid ratio 1/20) containing $50 \mathrm{mM}$ TRIS-HCl buffer (pH 8.0) with $5 \mathrm{mM} \mathrm{CaCl}_{2}$. The enzyme concentration of G51 proteases or Esperase 8.0 L (SIGMA) was $7.5 \mathrm{CAU} / \mathrm{mL}$ of the bath. Controls without enzymes were also performed. Five independent replicas of each treatment were processed. Treatments were conducted at $45^{\circ} \mathrm{C}$ and $30 \mathrm{rpm}$ for $1 \mathrm{~h}$. After incubation, wool fibers were removed, washed thoroughly, and air-dried. Thereafter, wool fibers were kept at $50^{\circ} \mathrm{C}$ for $2 \mathrm{~h}$, desiccated, and weighted until constant weight (considered as differences between successive weights inferior to $1 \mathrm{mg}$ ) [12]. Loose wool feltability was determined using a modified Aachen felt test [27]. Felt-ball diameter was measured at three places and the values averaged, on five felt-ball independent replicas for each treatment. Then, the felt-ball density was calculated (IWTO-20-04). An increase in felt-ball diameter, and consequently a decrease of felt-ball density, indicates a smaller felting propensity (and vice versa). The significance of the differences in felt-ball diameter and density among treatments was evaluated by one-way ANOVA. Tukey was used for multiple comparisons. As 
the percentage of weight loss between control and protease treatments did not accomplish ANOVA assumptions, the Mann-Whitney test was performed. Statistical analyses were carried out with SPSS 7.0 package [28].

\section{Results and discussion}

\section{Screening and selection of protease-producing bacteria from Patagonian Merino wool}

A lot of effort has been concentrated on the development of environmental acceptable felt-resist treatments for wool, mainly using commercial proteases or their modifications
$[10,11,13,14]$. The bioprospection of microbial diversity might also provide keratinases or natural mixtures of them with interesting properties for organic wool processing [7]. From 135 bacterial isolates of Patagonian Merino wool, 66 showed proteolytic activity (23 were isolated on SM agar, 20 on HAV agar, and 23 after enrichment in MSM). Figure $1 \mathrm{a}, \mathrm{b}$ shows the diameters of the halos of culture supernatants of the isolates with higher proteolytic activity, obtained by the spot technique on SM agar, after 1 and 3 days of incubation. Culture supernatants of most of such isolates also presented keratinolytic activity on Merino wool (Fig. 1c). From the isolates with higher keratinolytic activity, 7 corresponded to the genus Bacillus (G11, G21, G40, G49, G51, H23, and H36) and only one
Fig. 1 Diameters of the halos produced by spots $(5 \mu \mathrm{L})$ of culture supernatants of Patagonian Merino isolates on SM agar plates after 1 (grey part of the bars) and 3 days of incubation (grey plus white parts of the bars). a Strains isolated from wool samples incubated in MSM medium (G11, G21, G35, G40, G53) and on SM agar (rest of the isolates); $\mathbf{b}$ strains isolated on HAV agar; c keratinolytic activity of culture supernatants of isolates from Patagonian Merino wool. Data: means $(n=3) \pm 1 \mathrm{SE}$
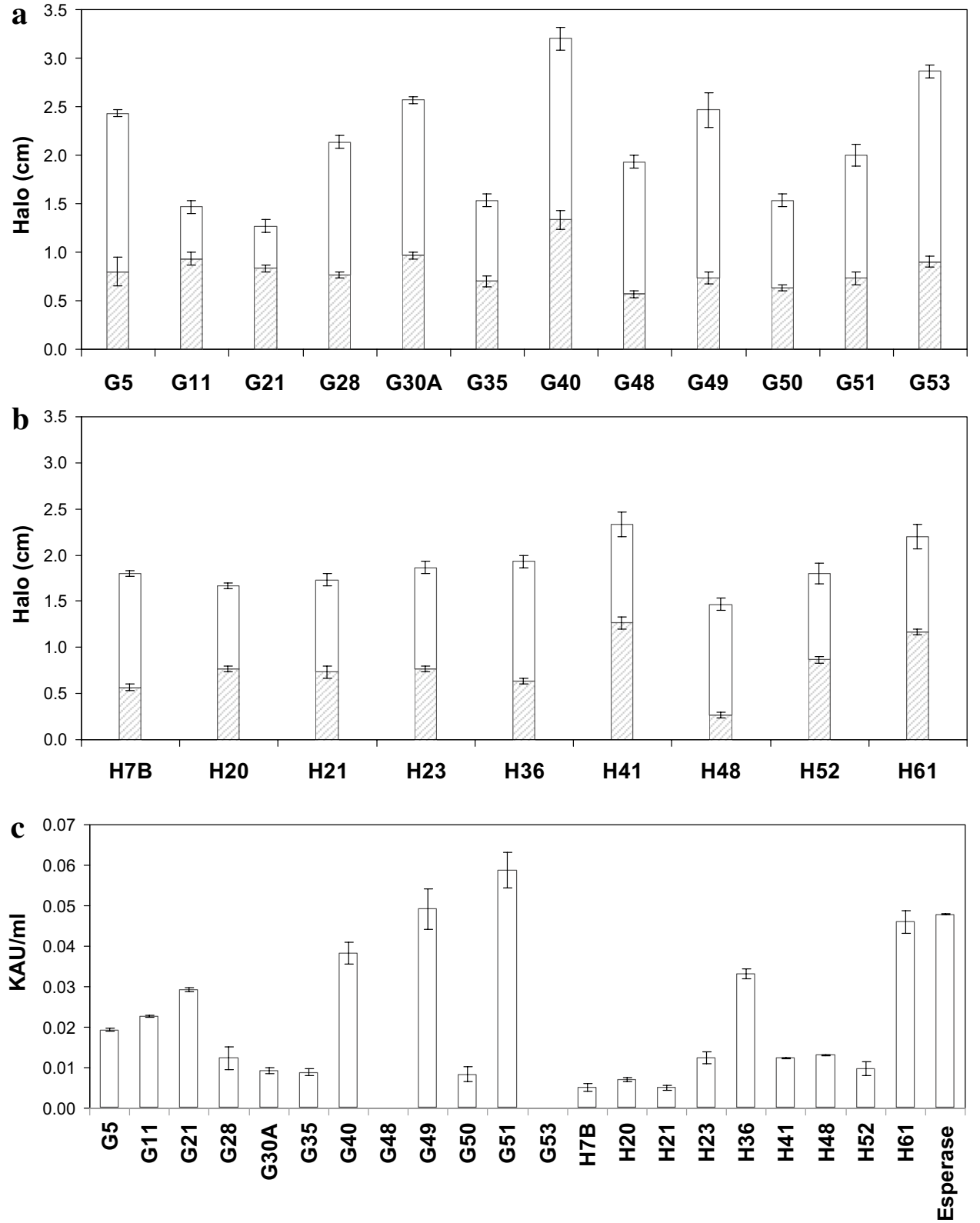
to each of the genera Exiguobacterium (G5), Deinococcus (H48), and Micrococcus (H61), (Online Resource 1). Few studies have screened wool bacteria as a source of keratinolytic enzymes, thus the knowledge about its usefulness for wool processing is limited. Bacillus sp. strain HTS 102, isolated from Portuguese autochthonous sheep, produces a strong and stable protease with keratinolytic activity [19]. Infante et al. [29] isolated Bacillus thuringiensis L11 from Merino wool which produces an extracellular protease with potential for the textile industry. In this study, isolate G51 was selected for enzymatic treatment of wool as it showed the highest wool keratinolytic activity (Fig. 1c). G51 16S rRNA gene sequence $(\sim 1,400 \mathrm{bp})$ shared $99.93 \%$ similarity with that of Bacillus subtilis sp. inaquosorum $13429^{\mathrm{T}}$, a GRAS (generally recognized as safe) species with valuable biotechnological characteristics.

\section{Bacillus sp. G51 extracellular proteolytic activity}

The optimal temperature for proteolytic activity of Bacillus sp. G51 was approximately $60^{\circ} \mathrm{C}$ (Fig. 2a). It was stable at moderate temperatures, showing about $90 \%$ residual activity after $2 \mathrm{~h}$ of incubation at $40^{\circ} \mathrm{C}$ (Fig. $2 \mathrm{~b}$ ). The residual proteolytic activity decreased to approximately $30 \%$ after
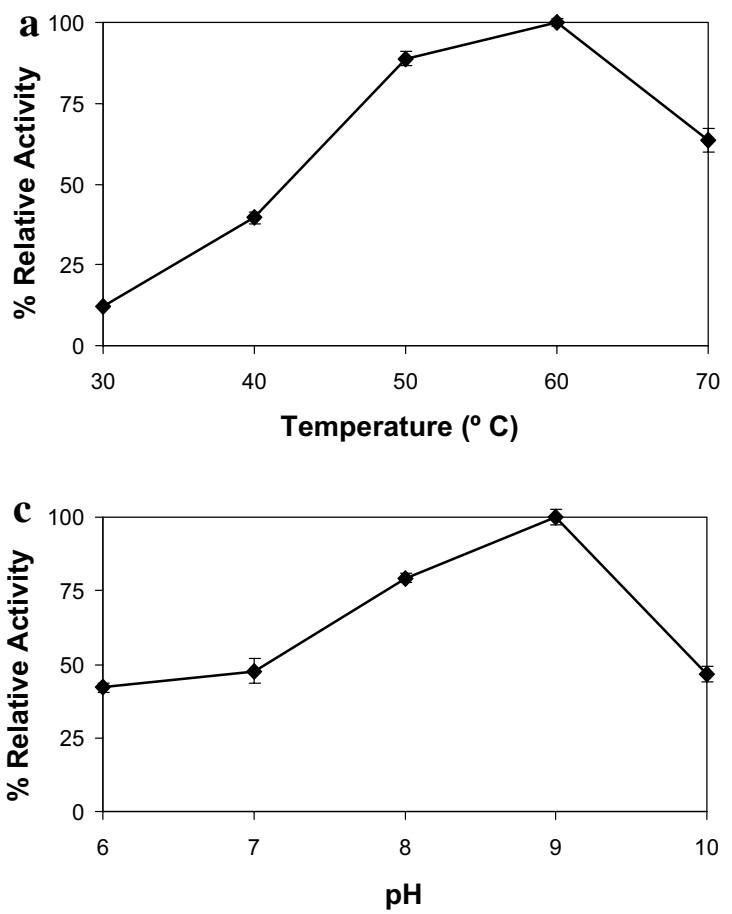

Fig. 2 Effects of temperature and $\mathrm{pH}$ on the activity and stability of Bacillus sp. G51 proteolytic activity. a Determination of optimal temperature for activity. b Determination of thermal stability; cell-free supernatant was incubated at 40 (filled diamond), 50 (filled square), 60 (filled triangle) and $70{ }^{\circ} \mathrm{C}$ (cross) without substrate, and then the residual activity was measured. c Determination of optimal $\mathrm{pH}$ for
$2 \mathrm{~h}$ at $50^{\circ} \mathrm{C}$, and no residual activity was detected after $2 \mathrm{~h}$ at $60^{\circ} \mathrm{C}$ (Fig. 2b). Moreover, proteolytic activity was highly stable in the $\mathrm{pH}$ range of $6.0-11.0$, with an optimum for activity at $\mathrm{pH} 9.0$ (Fig. 2c, d). Feather-degrading serine proteases from Bacillus mojavensis A21 showed optimum $\mathrm{pH}$ for proteolytic activity between 8.0 and 11.0 [30]. The optimum $\mathrm{pH}$ of proteases produced by wool-degrading Bacillus amyloliquefaciens MA20 and B. subtilis MA21 was 9.0 [31]. A positive characteristic of G51 proteolytic activity was its high stability to non-ionic surfactants (Triton X-100 and Tween 20) and to surfactants used in wool processing (Lipocol OXO 650 and Teridol B), (Table 1). In contrast, residual activity decreased to approximately $40 \%$ with the anionic surfactant SDS (Table 1). Even though $\mathrm{Ca}^{2+}$ may provide structural and thermal stability to some proteases, it only marginally enhanced the proteolytic activity of G51 (Table 1). $\mathrm{Zn}^{2+}$ reduced G51 proteolytic activity (Table 1); this could be related with inhibition of metalloproteases due to the additional binding of $\mathrm{Zn}^{2+}$ (in the $\mathrm{mM}$ range) to the binding site [32]. In addition, the high stability of G51 proteolytic activity to $\mathrm{H}_{2} \mathrm{O}_{2}$ is an important feature (Table 1), as this is used as a bleaching agent and in wool shrink-resist pre-treatments $[11,12,33]$.
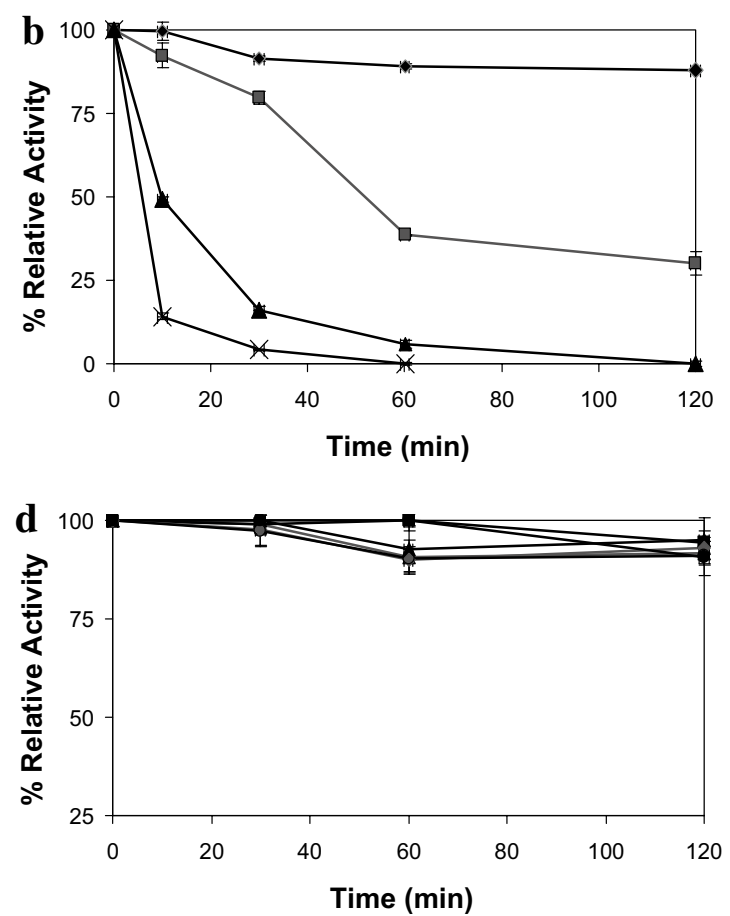

activity. d pH stability experiments; enzyme extract was incubated in buffers with the following $\mathrm{pH}$ values 6 (open triangle), 7 (filled square). 8 (filled triangle), 9 (filled diamond), 10 (filled circle) and 11 (open circle), and then the residual activity was determined. The $100 \%$ value for the proteolytic activity corresponded to $1.5 \mathrm{CAU} / \mathrm{mL}$. Data: means $(n=3) \pm 1 \mathrm{SE}$ 
Table 1 Effect of protease inhibitors and chemical agents on Bacillus sp. G51 proteolytic activity

\begin{tabular}{llr}
\hline Chemical agents & Concentration & Residual activity (\%) \\
\hline E64 & $0.1 \mathrm{mM}$ & $95.05 \pm 1.06$ \\
Iodoacetamide & $0.1 \mathrm{mM}$ & $103.00 \pm 5.46$ \\
PMSF & $1 \mathrm{mM}$ & $41.32 \pm 1.09$ \\
PMSF & $10 \mathrm{mM}$ & $34.50 \pm 3.18$ \\
EDTA & $10 \mathrm{mM}$ & $27.68 \pm 0.73$ \\
$1,10-$ Phenanthroline & $10 \mathrm{mM}$ & $37.69 \pm 1.02$ \\
Triton X-100 & $1 \% \mathrm{v} / \mathrm{v}$ & $102.97 \pm 3.88$ \\
Triton X-100 & $5 \% \mathrm{v} / \mathrm{v}$ & $80.52 \pm 2.07$ \\
Tween 20 & $1 \% \mathrm{v} / \mathrm{v}$ & $111.31 \pm 3.04$ \\
Tween 20 & $5 \% \mathrm{v} / \mathrm{v}$ & $121.97 \pm 3.73$ \\
SDS & $1 \% \mathrm{w} / \mathrm{v}$ & $38.98 \pm 1.69$ \\
Lipocol OXO $650^{\text {Teridol B }}$ & $1 \% \mathrm{v} / \mathrm{v}$ & $99.86 \pm 2.19$ \\
$\beta-\mathrm{Mercaptoethanol}_{\text {DTT }}$ & $1 \% \mathrm{v} / \mathrm{v}$ & $98.36 \pm 6.00$ \\
$\mathrm{H}_{2} \mathrm{O}_{2}$ & $5 \mathrm{mM}$ & $83.92 \pm 8.40$ \\
$\mathrm{ZnSO}_{4}$ & $5 \mathrm{mM}$ & $71.63 \pm 4.33$ \\
$\mathrm{CaCl}_{2}$ & $1 \%$ & $97.01 \pm 0.29$ \\
\hline
\end{tabular}

Data: means $(n=3) \pm 1 \mathrm{SE}$

G51 proteolytic activity was not inhibited by the inhibitors for cysteine proteases E-64 and iodoacetamide (Table 1). In contrast, it was partially inhibited by the serine protease inhibitor PMSF and the metalloprotease inhibitors EDTA and 1,10-phenanthroline (Table 1), suggesting a mixture of serine and metalloproteases in G51 culture supernatant. Non-reducing SDS-PAGE and zymogram showed a protein band with the highest proteolytic activity and the lowest electrophoretic mobility (Fig. 3, band 1) and other bands with lower activity and different mobility (Fig. 3, bands 2 and 3). LC-MS/MS analysis of released tryptic peptides of those bands resulted in the identification of peptides belonging to different proteases (Table 2). Proteolytic band 1 was associated with Subtilisin E (Table 2; Fig. 3), an extracellular enzyme with $\mathrm{Ca}^{2+}$ ions as cofactor. Proteolytic bands 2 and 3 delivered peptides matching with the metalloprotease Bacillolysin and with an intracellular serine protease, respectively (Table 2; Fig. 3). The serine proteases belong to the peptidase family S8 of MEROPS database that contains Subtilisin and its homologues. Subtilisin-like serine proteases show a preference for cleavage after hydrophobic residues or dibasic amino acids, and are important in the degradation of keratinaceous substrates $[34,35]$. Other studies demonstrated that Subtilisins with high specificity for aromatic and hydrophobic amino acids in the P1 substrate position efficiently degraded feather keratin, possibly due to the number of residues either aromatic or hydrophobic (approximately 50\%) found in keratin

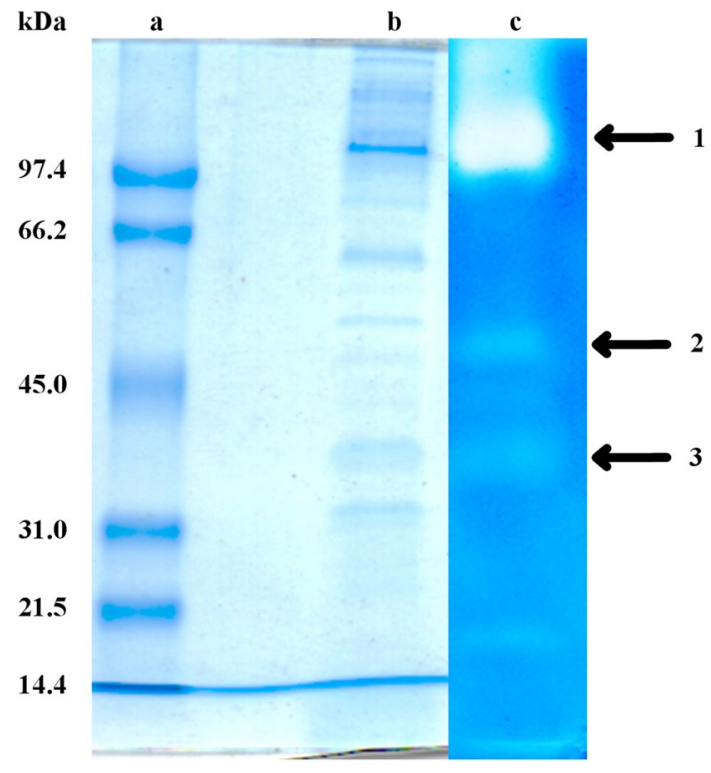

Fig. 3 Non-reducing SDS-PAGE and zymogram analysis from culture supernatant of Bacillus sp. G51. Line a Low range molecular mass markers (Bio-Rad). Line $b$ protein profile of culture supernatant of Bacillus sp. G51. Line c culture supernatant of Bacillus sp. G51 zymogram. 1, 2, and 3 bands with proteolytic activity

molecules [36, 37]. Bacillolysin (family M4) is an extracellular $\mathrm{Zn}^{2+}$ dependent enzyme with four $\mathrm{Ca}^{2+}$ ions as cofactor. Most members of family M4 degraded proteins and peptides with a preference for cleavage of Xaa + Yaa, in which Xaa is a hydrophobic residue and Yaa is Leu, Phe, Ile, or Val (http://merops.sanger.ac.uk).

Interestingly, protein bands 2 and 3 also delivered peptides matching with dihydrolipoyl dehydrogenases and $\gamma$-glutamyltranspeptidase (GTT) which could be involved in keratin degradation (Table 2). In addition to hydrogen bonds and hydrophobic interactions, keratin is strongly stabilized by cross-linking of protein chains through disulfide bonds [35]. The secondary structural conformation of wool keratin corresponds to hard $\alpha$-keratin which is characterized by a high level of disulfide bonds, and hence high recalcitrance to proteolytic degradation [38]. Sulfitolysis, the breakdown of disulfide bonds, might be accomplished by disulfide reductases, chemical or live cell redox [39]. Previous findings suggested that keratin degradation is a cooperative process which includes keratinases and disulfide reductases [40-42]. Dihydrolipoyl dehydrogenases are disulfide oxidoreductases that catalyze the oxidation of dihydrolipoamide to lipoamide. GTT is one of the enzymes (aminoacyltransferase/ hydrolase) implicated in feather keratin degradation by B. subtilis $\mathrm{CH}-1$ [40]. A monomeric GGT30 from Bacillus licheniformis ER-15, produced by proteolytic digestion of a GGT67 by Subtilisin, assists Subtilisin during cell free degradation of $\alpha$-keratin of hooves and nails 
Table 2 Proteins identified by LC-MS/MS analysis

\begin{tabular}{|c|c|c|c|c|}
\hline Band & Accession code & Sequence description & $\begin{array}{l}\text { Number of } \\
\text { unique pep- } \\
\text { tides }\end{array}$ & Enzyme description \\
\hline 1 & P04189 & Subtilisin E & 2 & Extracellular alkaline serine protease (EC 3.4.21.62). Family S8 \\
\hline \multirow[t]{4}{*}{2} & P68736 & Bacillolysin & 2 & Extracellular zinc metalloprotease (EC 3.4.24.28). Family M4 \\
\hline & P21880 & Dihydrolipoyl dehydrogenase & 5 & $\begin{array}{l}\text { Oxidoreductase (EC 1.8.1.4). Class-I pyridine nucleotide- } \\
\text { disulfide oxidoreductase family }\end{array}$ \\
\hline & P54533 & Dihydrolipoyl dehydrogenase & 3 & Oxidoreductase (EC 1.8.1.4) \\
\hline & P54422 & $\gamma$-glutamyl transpeptidase & 1 & $\gamma$-glutamyltransferase (EC 2.3.2.2). \\
\hline \multirow[t]{2}{*}{3} & P11018 & Major intracellular serine protease & 2 & Serine endopeptidase (EC 3.4.21). Family S8 \\
\hline & P54422 & $\gamma$-glutamyl transpeptidase & 4 & $\gamma$-glutamyltransferase (EC 2.3.2.2) \\
\hline
\end{tabular}

[43, 44]. Sharma and Gupta [42] demonstrated that $\gamma$-glutamyltranspeptidase (GGT)-glutathione (GSH) system is involved in the degradation of feathers by reducing disulfide bonds making them more vulnerable to keratinase attack.

Enzyme purification is an important factor for the industrial application of enzymes due to its impact on the production costs. In addition, purification steps may remove important components responsible for the reduction of keratin disulfide bonds [38, 41]. G51 crude enzyme extract has the advantage of containing a combination of different peptidases in addition to other enzymes that could be involved in the reduction of disulfide bonds (e.g. GTT) that may cooperate in the degradation of the wool cuticle, inducing the descaling of the fibers (Online Resource 2). In line with these results, Chaya et al. [45] found that only the crude enzymes secreted by Fusarium oxysporum 26-1 or the combination of two of them, rKrtA (S8 family peptidase) and rKrtC (M36 family peptidase), significantly descaled wool fibers. Congruently, Stenotrophomonas maltophilia BBE11-1 produced two keratinases and one protein with the ability to break disulfide bonds that degraded wool and feather in a synergic manner [46]. Moreover, G51 proteolytic activity showed high stability to $\beta$-mercaptoethanol and DTT (Table 1) which is another positive feature because reducing agents such as sodium sulphite, $\beta$-mercaptoethanol, cysteine, and DTT have been applied to enhance keratin sulfitolysis [37].

\section{Wool felt-resist treatment using G51 proteases}

Both Bacillus sp. G51 proteases and Esperase significantly increased the felt-ball diameter $(1.1$ and $1.2 \mathrm{~mm}$, respectively), and consequently decreased the felt-ball density, in comparison to those of untreated wool (Table 3; Fig. 4). It has been suggested that felt-ball diameter would only have to increase approximately to $30-32 \mathrm{~mm}$ to meet the machine wash specifications for the shrink-proofing feltball test [47]. Allam et al. [48] reached $30.2 \mathrm{~mm}$ felt-ball diameter (40.4 $\mu \mathrm{m}$ wool fiber) by optimizing a keratinase treatment. In this study, the wool weight loss was low $(<1.5 \%)$ for all treatments. Particularly, the weight loss of wool treated with Bacillus sp. G51 proteases did not differ significantly from that of the control treatment (Table 3). This low weight loss of wool could be related with the moderate incubation conditions selected for the treatment with G51 proteases far from the optimal $\mathrm{pH}$ and temperature conditions (Fig. 2). On the other hand, wool treatment with Esperase resulted in a significantly higher weight loss than in controls (Table 3). In line with these results, partial descaling of the wool fibers was observed after wool treatment with G51 proteases, while regions with excessive enzymatic attack to the fiber were detected in Esperase treated wool (Online Resource 2). After wool treatment with native proteases from Bacillus lentus and B. subtilis, Jus et al. [49] reported a similar increase in felt-ball diameters to that found in this study but with higher weight losses (4.79 and $14.67 \%$, respectively, after $180 \mathrm{~min}$ incubation).

Table 3 Weight loss, felt-ball diameter and density of wool top treated with Bacillus sp. G51 proteases, Esperase (SIGMA), and control without enzymes

\begin{tabular}{llll}
\hline Treatment & Felt-ball diameter $(\mathrm{cm})$ & Felt-ball density $\left(\mathrm{g} / \mathrm{cm}^{3}\right)$ & Weight loss $(\%)$ \\
\hline Esperase & $3.00 \pm 0.02 \mathrm{~b}$ & $0.068 \pm 0.001 \mathrm{a}$ & $1.09 \pm 0.14 \mathrm{~b}$ \\
G51 proteases & $2.99 \pm 0.03 \mathrm{~b}$ & $0.071 \pm 0.003 \mathrm{a}$ & $0.31 \pm 0.08 \mathrm{a}$ \\
Control without enzymes & $2.88 \pm 0.01 \mathrm{a}$ & $0.079 \pm 0.001 \mathrm{~b}$ & $0.38 \pm 0.06 \mathrm{a}$ \\
\hline
\end{tabular}

Data: means $(n=5) \pm 1$ SE. Lowercase letters: significant differences among treatments $(p<0.05)$ 


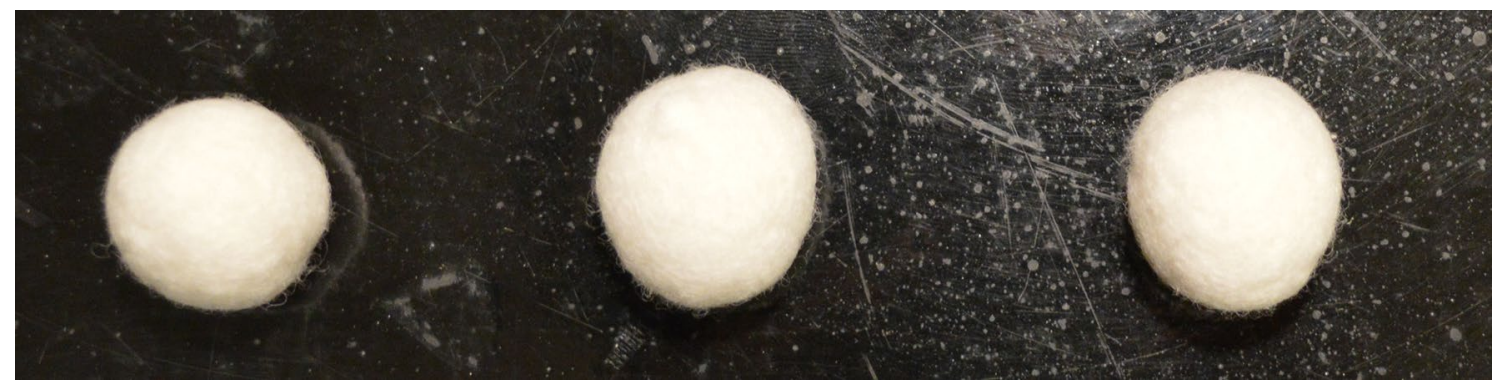

Fig. 4 Wool felt-balls after treatments (from left to right): control without enzymes, Bacillus sp. G51 proteases, and Esperase

High weight loss values have been associated with the diffusion of proteases inside the wool fiber causing undesirable hydrolysis and strength loss [2]. It was reported that commercial processes aim for a 3-6\% weight loss after enzymatic hydrolysis [50].

\section{Conclusion}

Enzymatic treatments could be an environmentally friendly alternative for reducing top felting. Patagonian Merino wool harbor bacteria from different genera which secreted wool-degrading enzymes. Bacillus sp. G51 produced a combination of extracellular serine and metallopeptidases which caused a decrease in felting tendency of wool top without significant weight loss. This treatment based on peptidases from a wild bacterium has potential for meeting the demands of organic wool processing which bans the use of hazardous chemicals and genetic engineering.

Acknowledgements The authors acknowledge to Fuhrmann S.A. for kindly providing wool tops and to UNILAN Trelew S.A., Lanera Austral S.A., Estancia San Guillermo, and Estancia Don Martín for raw wool samples. The authors are also grateful to Jaime Groizard (ALUAR Aluminio Argentino) for scanning electron micrographs. This work was supported by the Agencia Nacional de Promoción Científica y Tecnológica (ANPCyT), Ministerio de Ciencia, Tecnología e Innovación Productiva, Argentina (PICT Start Up 20122004); and the Consejo Nacional de Investigaciones Científicas y Técnicas (CONICET), Argentina (PIP 11220120100050CO). Martín Iglesias is grateful to ANPCyT for his Ph.D. grant.

\section{Compliance with ethical standards}

Conflict of interest No conflict of interest declared.

\section{References}

1. Plowman JE, Deb-Choudhury S, Clerens S, Thomas A, Cornellison CD, Dyer JM (2012) Unravelling the proteome of wool: towards markers of wool quality traits. J Proteomics $75: 4315-4324$
2. Fu J, Su J, Wang P, Yu Y, Wang Q, Cavaco-Paulo A (2015) Enzymatic processing of protein-based fibers. Appl Microbiol Biotechnol 99:10387-10397

3. Shen J (2009) In: Johnson NAG, Russell IM (eds) Advances in wool technology, 1st edn. Woodhead Publishing in Textiles, Cambridge

4. Holt RRD (1975) Introduction to Superwash wool. JSDC February: 38-44.

5. Buschle-Diller G (2003) In: Cavaco-Paulo A, Gübitz GM (eds) Textile processing with enzymes, 1st edn. Woodhead Publishing Ltd, Cambridge.

6. Ladwig H, Stopes C, Arbenz M, Lernoud J (2015) Organic opportunities and challenges: the next generation of the wool industry. In: Global Organic Textile Standart (GOTS). http://www.global-standard.org/images/stories/Why_GOTS_ Factsheets/GOTS_WoolPoster_June2015_low.pdf. Accessed 25 Nov 2016

7. GOTS (2014) Version 4.0 Global Organic Textile Standard International Working Group. http://global-standard.org/thestandard.html. Accessed 25 Nov 2016

8. Shen J (2010) In: Nierstrasz VA, Cavaco-Paulo A (eds) Advances in textile biotechnology, 1st edn. Woodhead Publishing in Textiles. Cambridge

9. Cegarra J, Pepió M, Naik A, Riva A (2004) Modelización de la acción de una proteasa en las características físicas de un tejido de lana. Boletín Intexter (UPC) 125:9-18.

10. Kotlińska A, Lipp-Symonowicz B (2011) Research on the enzymatic treatment of wool fibres and changes in selected properties of wool. Fibres Text East Eur 19:88-93.

11. Lenting HBM, Schroeder M, Guebitz GM, Cavaco-Paulo A, Shen J (2006) New enzyme-based process direction to prevent wool shrinking without substantial tensile strength loss. Biotechnol Lett 28:711-716

12. Araújo R, Silva C, Machado R, Casal M, Cunha AM, Rodriguez-Cabello JC, Cavaco-Paulo A (2009) Proteolytic enzyme engineering: a tool for wool. Biomacromolecules 10:1655-1661

13. Shen J, Rushforth M, Cavaco-Paulo A, Guebitz G, Lenting H (2007) Development and industrialisation of enzymatic shrinkresist process based on modified proteases for wool machine washability. Enzyme Microb Technol 40:1656-1661

14. Silva CJSM, Prabaharan M, Gubitz G, Cavaco-Paulo A (2005) Treatment of wool fibres with subtilisin and subtilisin-PEG. Enzyme Microb Technol 36:917-922

15. Liu B, Zhang J, Xiangru-Liao BL, Du G, Chen J (2013) Expression and characterization of extreme alkaline, oxidation-resistant keratinase from Bacillus licheniformis in recombinant Bacillus subtilis WB600 expression system and its application in wool fiber processing. World J Microbiol Biotechnol 29:825-832 
16. HERA (2007) Human and environmental risk assessment on ingredients of household cleaning products. Subtilisins (Protease). http://www.heraproject.com/files/22-F-07_PROTEASE_ HERA_Final\%20Edition\%20(unsecured\%20-\%20PDFA-1b).pdf. Accessed 25 Nov 2016

17. Hayakawa M, Nonomura H (1987) Humic acid-vitamin agar, a new medium for the selective isolation of soil actinomycetes. $\mathrm{J}$ Ferment Technol 65:501-509

18. Sousa F, Jus S, Erbel A, Kokol V, Cavaco-Paulo A, Gubitz GM (2007) A novel metalloprotease from Bacillus cereus for protein fibre processing. Enzyme Microb Technol 40:1772-1781

19. Queiroga AC, Pintado MM, Malcata FX (2007) Novel microbial-mediated modifications of wool. Enzyme Microb Technol 40:1491-1495

20. Olivera N, Siñeriz F, Breccia JD (2005) Bacillus patagoniensis sp. nov., a novel alkalitolerant bacterium from the rhizosphere of Atriplex lampa in Patagonia, Argentina. Int J Syst Evol Microbiol 55:443-447

21. Kim OS, Cho YJ, Lee K, Yoon SH, Kim M, Na H, Park SC, Jeon YS, Lee JH, Yi H, Won S, Chun J (2012) Introducing EzTaxone: a prokaryotic $16 \mathrm{~S}$ rRNA gene sequence database with phylotypes that represent uncultured species. Int J Syst Evol Microbiol 62:716-721

22. Moreira FG, De Souza CGM, Costa MAF, Reis S, Peralta RM (2007) Degradation of keratinous materials by the plant pathogenic fungus Myrothecium verrucaria. Mycopathologia 163:153-160

23. Cupp-Enyard C (2008) Sigma's non-specific protease activity assay-casein as a substrate. J Vis Exp 19:899

24. Good NE, Izawa S (1972) Hydrogen ion buffers. Methods Enzymol 24:53-68

25. Neuhoff V, Stamm R, Pardowitz I, Arold N, Ehrhardt W, Taube D (1990) Essential problems in quantification of proteins following colloidal staining with Coomassie Brilliant Blue dyes in polyacrylamide gels, and their solution. Electrophoresis 11:101-117

26. Westergaard JL, Hackbarth C, Treuhaft MW, Roberts RC (1980) Detection of proteinases in electrophoretograms of complex mixtures. J Immunol Methods 34:167-175

27. Kenyon PR, Wickham GA (1999) A New technique for measuring loose-wool feltability. J Text Inst 90:266-268

28. Norušis MJ (1997) SPSS 7.5 Guide to Data Analysis. Prentice Hall, New Jersey

29. Infante I, Morel MA, Ubalde MC, Martínez-Rosales C, Belvisi S, Castro-Sowinski S (2010) Wool-degrading Bacillus isolates: extracellular protease production for microbial processing of fabrics. World J Microbiol Biotechnol 26:1047-1052

30. Haddar A, Sellami-Kamoun A, Fakhfakh-Zouari N, Hmidet N, Nasri M (2010) Characterization of detergent stable and feather degrading serine proteases from Bacillus mojavensis A21. Biochem Eng J 51:53-63

31. Hassan MA, Haroun BM, Amara AA, Serour EA (2013) Production and characterization of keratinolytic protease from new wool-degrading Bacillus species isolated from Egyptian ecosystem. BioMed Res Int 2013:1-14.

32. Lee DG, Jeon JH, Jang MK, Kim NY, Lee JH, Lee JH, Kim SJ, Kim GD, Lee SH (2007) Screening and characterization of a novel fibrinolytic metalloprotease from a metagenomic library. Biotechnol Lett 29:465-472
33. Ibrahim NA, El-Shafei HA, Abdel-Aziz MS, Ghaly MF, Eid BM, Hamed AA (2012) The potential use of alkaline protease from Streptomyces albidoflavus as an eco-friendly wool modifier. J Text Inst 103:490-498

34. Daroit DJ, Brandelli A (2013) A current assessment on the production of bacterial keratinases. Crit Rev Biotechnol 34:372-384

35. Lange L, Huang Y, Busk PK (2016) Microbial decomposition of keratin in nature-a new hypothesis of industrial relevance. Appl Microbiol Biotechnol 100:2083-2096

36. Evans KL, Crowder J, Miller ES (2000) Subtilisins of Bacillus spp. hydrolyze keratin and allow growth on feathers. Can J Microbiol 46:1004-1011

37. Ramnani P, Gupta R (2007) Keratinases vis-à-vis conventional proteases and feather degradation. World J Microbiol Biotechnol 23:1537-1540

38. Brandelli A, Daroit DJ, Riffel A (2010) Biochemical features of microbial keratinases and their production and applications. Appl Microbio Biotechnol 85:1735-1750

39. Gupta R, Sharma R, Beg QK (2012) Revisiting microbial keratinases: next generation proteases for sustainable biotechnology. Crit Rev Biotechnol 30:1-13

40. Liu Q, Zhang T, Song N, Li Q, Wang Z, Zhang X, Lu X, Fang J, Chen J (2014) Purification and characterization of four key enzymes from a feather-degrading Bacillus subtilis from the gut of tarantula Chilobrachys guangxiensis. Int Biodeter Biodegrad 96:26-32.

41. Rahayu S, Syah D, Suhartono MT (2012) Degradation of keratin by keratinase and disulfide reductase from Bacillus sp. MTS of Indonesian origin. Biocatal Agric Biotechnol 1:152-158.

42. Sharma R, Gupta R (2012) Coupled action of $\gamma$-glutamyl transpeptidase-glutathione and keratinase effectively degrades feather keratin and surrogate prion protein, Sup 35NM. Bioresour Technol 120:314-317

43. Tiwary E, Gupta R (2010) Improved catalytic efficiency of a monomeric $\gamma$-glutamyl transpeptidase from Bacillus licheniformis in presence of subtilisin. Biotechnol Lett 32:1137-1141

44. Tiwary E, Gupta R (2010) Subtilisin- $\gamma$-glutamyl transpeptidase: a novel combination as ungual enhancer for prospective topical application. J Pharma Sci 99:4866-4873

45. Chaya E, Suzuki T, Karita S, Hanya A, Yoshino-Yasuda S, Kitamoto N (2014) Sequence analysis and heterologous expression of the wool cuticle-degrading enzyme encoding genes in Fusarium oxysporum 26-1. J Biosci Bioeng 117:711-714

46. Fang Z, Zhang J, Liu B, Du G, Chen J (2013) Biochemical characterization of three keratinolytic enzymes from Stenotrophomonas maltophilia BBE11-1 for biodegrading keratin wastes. Int Biodeter Biodegrad 82:166-172.

47. Greeff JC, Schlink AC (2002) The inheritance of felting of merino wool. Proc Assoc Advmt Anim Breed Genet 14:497-500.

48. Allam OG, Mowafi S, El-kheir AA, Abdel-fattah AM, Bendak A (2015) Effect of extracted Egyptian keratinase on the properties of native coarse wool. Int J Adv Res 3:994-1003

49. Jus S, Schroeder M, Guebitz GM, Heine E, Kokol V (2007) The influence of enzymatic treatment on wool fibre properties using PEG-modified proteases. Enzyme Microb Technol 40:1705-1171

50. Jovančić P, Jocić D, Dumić J (1998) The efficiency of an enzyme treatment in reducing wool shrinkage. J Text Inst 89:390-400 